\title{
REVEALING THE SUCCESS OF RENITA ENCENG GONDOK IN MAINTAINING ITS BUSINESS EXISTENCE
}

\author{
Eka wahyu liana ${ }^{1}$
}

Rr. Lulus Prapti N.S.S ${ }^{2}$

Dian Triyani $^{3}$

Faculty of Economics, Universitas Semarang

\begin{abstract}
This research was conducted at the Renita Eceng Gondok SME, Demakan, Banyubiru, Ambarawa, Semarang in the marketing and production section. The aim of this study is to explore the success of the Renita Eceng SME business in maintaining its existence. This study is a case study with triangulation of data sources, observation data, interviews, documentation, and narratives. Informant study is based on the appropriate principle and adequacy. There are 6 basic informant principles in this study. The results of this study indicate that the strategy of Renita Eceng Gondok in achieving success and maintaining its existence is paying attention on material quality and improve the skill of their employee (human resources). The way of Renita Enceng Gondok explores creative ideas in creating variety of superior Enceng Gondok handycrafts products is by looking for patterns from internet then they developed the pattern based on the instruction from the owner of Renita Eceng Gondok. These ideas were turn into shoes, sandals, paper towels, jars, trash bins, frame, miniatures, and glass for hotel construction, laundry baskets, and others. The government supports this SME by facilitating exhibitions, training in management, marketing, equipments, etc.
\end{abstract}

Keywords: Business Strategy, Business Success, Business Existence.

\footnotetext{
1,21ulus_prapti@yahoo.com; Faculty of Economics, Universitas Semarang

3 diantriyaniyanata@gmail.com; Faculty of Economics, Universitas Semarang
} 


\section{INTRODUCTION}

Semarang Regency have many tourist attractions and also have an industrial area that has a variety of potential district advantage, including convection crafts, embroidery crafts, rug crafts, children's toy crafts, bamboo crafts, culinary craft, and Enceng Gondok crafts. Potential product advantages of SME in Semarang are mostly done traditionally using simple equipment. One of the creative industry sectors that have great potential to be utilized is Enceng Gondok handycrafts industry. This industry use creativity, skills and talent to produces many variations of products, including sandals, bags, furniture, and souvenirs. Rawa Pening is a Lake that becomes a habitat for Enceng Gondok and it is located in Semarang Regency. Rawa Pening is a semi-natural lake with 2,670 hectares of width located in four sub-districts, namely Ambarawa, Tuntang, Bawen, and Banyu Biru. (Onixtin Octarina Sianturi and Wido Prananing Tyas, .2018).

Since its establishment, the number of Enceng Gondok craftsmen in Banyubiru keep increasing until there are lot of Enceng Gondok craftsmen in Banyubiru District, Renita Enceng Gondok continue to innovate and maintain its existence as a Enceng Gondok craftsman. The products that were produced by Renita Enceng Gondok were purchase and were used as a hobby for Enceng Gondok craft hunters. Renita Enceng Gondok is one of Enceng Gondok craftsmen who are successfully running their business though it is still included as SME in Banyubiru, Semarang Regency. Marketing of Enceng Gondok handycrafts products for SMEs in Banyubiru, Semarang Regency also use online media, www.krajinanambarawa.com. By using the internet it can be seen that the businessman utilizing business opportunities. Although the Enceng Gondok craft with raw materials comes from nature and tends to be traditional, the current trend of using technology can also be used by all groups. This condition help the community in developing their business easily by utilizing Enceng Gondok to turn it into something that has economic value so that SME can maintain its existence due to tight business competition.

Even though the beginning of the establishment of Renita Eceng Gondok in 1996 it did not go well, it stopped for two years due to the inhibition of venture capital and other problem, and then Mr. Slamet was determined to rebuild the business in 1999 until now. Tough it had a bad start, this business was able to develop and exist for twenty-two-year 
and win several SME competitions and conduct some training throughout Indonesia. Renita Enceng Gondok still can maintain its existence until now.

Table 1

Sales Progress of Renita Eceng Gondok Demakan, Banyubiru, Ambarawa Semarang Regency Period 2015 - 2019

\begin{tabular}{lll}
\hline Years & Sales & Turnover $(\mathbf{R p})$ \\
\hline $\mathbf{2 0 1 5}$ & 8800 & 90.000 .000 \\
$\mathbf{2 0 1 6}$ & 9600 & 102.600 .000 \\
$\mathbf{2 0 1 7}$ & 9800 & 108.000 .000 \\
$\mathbf{2 0 1 8}$ & 12000 & 134.000 .000 \\
$\mathbf{2 0 1 9}$ & 18000 & 156.000 .000 \\
\hline
\end{tabular}

Source: Sales Progress of Renita Eceng Gondok, 2015-2019

From the table above, it can be seen that the sale from year to year keep increasing and it will lead to the significantly increased sales turnover at the Renita Eceng Gondok

\section{Research Objectives}

1) To find out the strategy of Renita Eceng Gondok in achieving success and maintaining the existence of its business. 2) To find out how Renita Enceng Gondok explores its creative ideas in creating various Enceng Gondok handycrafts products advantage. 3) To find out how far the results of the ideas exploration can be turn into the process of creating a variety of product advantage as results. 4) To find out the form of Government support for the sustainability of the Renita Eceng Gondok business activities. 5) To find out the impact of Renita Eceng Gondok business activities in the environment around Banyubiru District. 6) To find out the supporting and inhibiting factors of Renita Eceng Gondok in achieving success and maintaining the existence of its business. 


\section{THEORETICAL BACKGROUND}

\section{A. Business Success}

The success of a business achieves its goals, where success is obtained from entrepreneurs who have an intelligent, that is creative, proactively follows and applied the development of technology, this can be seen from the effort of the entrepreneurs where a the condition is better than the previous period and describe more than others who are equal or in the same class.

\section{B. The Existence of Business}

There is nothing in daily life that has any characteristic or character that exists, other than humans. Only humans exist. Only humans are able to get out of themselves, transcending biological limitations, and their physical environment, trying not to be confined by all the limitations they have. Therefore, existentialists mention humans as a process, becoming active and dynamic motion.

\section{Micro, Small and Medium Enterprises (MSMEs)}

MSMEs are productive business units that are independent, carried out by individuals or business entities in all economic sectors. In principle, the distinction between Micro Business (UMi), Small Business (UK), Medium Business (UM) and Big Business (UB) is generally based on the value of initial assets (excluding land and buildings), average annual turnover or number of permanent workers. However, the definition of MSMEs based on these three measuring devices is different in each country (Tambunan, 2012). 
Research Flowchart

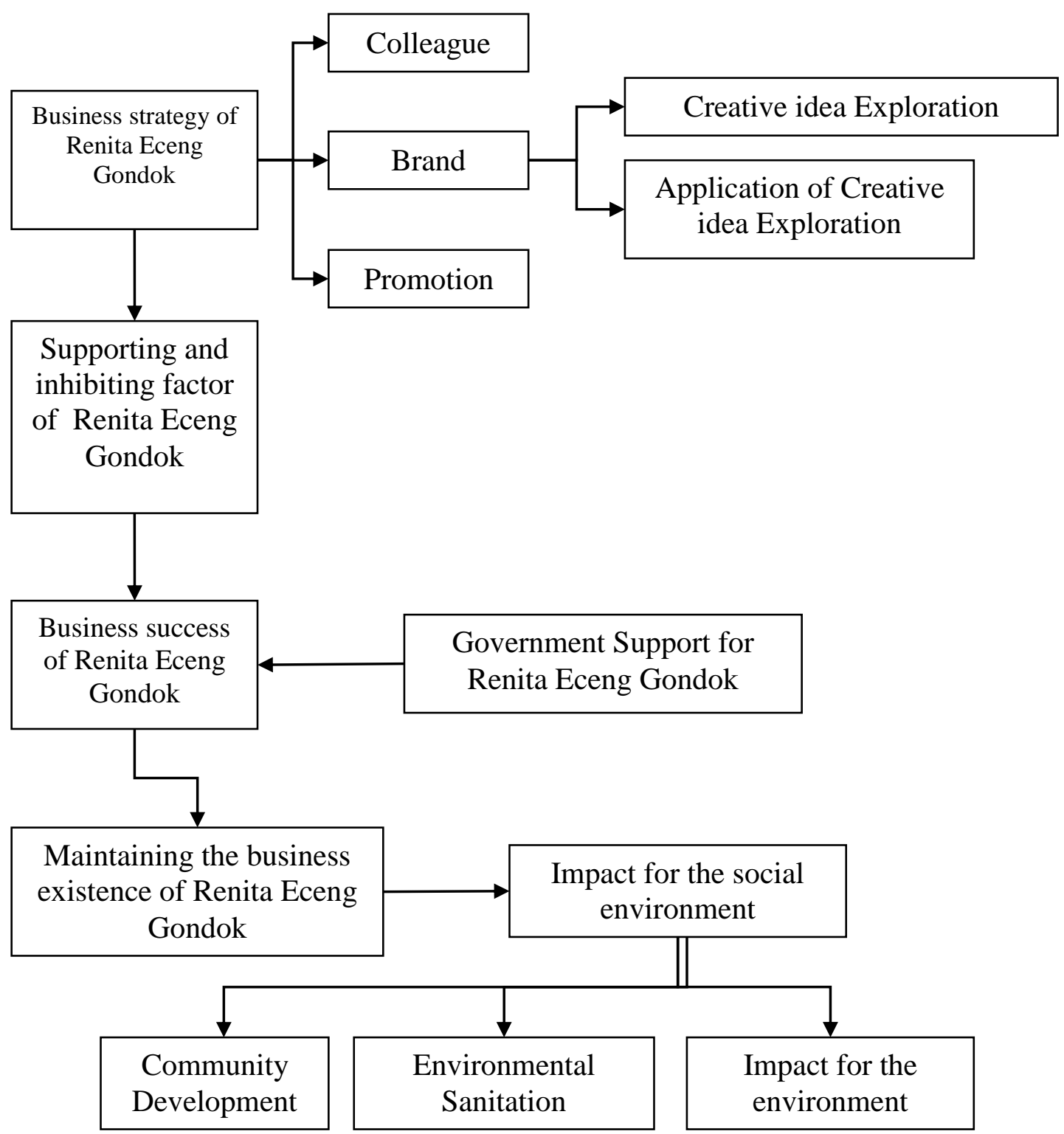

Gambar 1. Flow Chart

\section{METHOD, DATA AND ANALYSIS}

This type of research is research with a case study approach. Case study approach is a method used to obtain further data, a data that contains meaning. This study prioritizing detail explanations, breadth, and depth, then the analysis can be done optimally from the obtained results.

1) Observation

Observation is direct observation about field conditions, both in the form of 
physical and behavioral conditions that occur during the research

2) Interview

Interview is a method of collecting data by asking someone or more respondents by asking questions and answers face to face. In-depth interviews are conducted freely so that the data obtained are broad and in-depth data, but still pay attention to the guided element that enables to fulfill the principle of comparability and reliability directly to be directed and in favor of the issues under study.

3) Documentation

The documents used in this study are archived documents regarding the profile of MSMEs, production and sales activities, as well as other data that add information related to the object of this study.

\section{Data Credibility Test}

Data credibility test is a test used to assess the truth of qualitative research findings. Credibility was shown when participants revealed that the research transcript was truly his own experience.

1) Triangulation of Sources

By directing the researcher so, in collecting data, the researcher tries to use a variety of existing sources. For example, aside from interviews and observations, researchers can use engaging observations, written documents, archives, historical documents, official records, personal notes or writings and pictures or photographs.

2) Triangulation Methods

In this study, researchers used interview, observation, and documentation methods to compare and obtain reliable data and truth about how Renita Eceng Gondok maintains the success and the existence of its business.

\section{RESULTS AND DISCUSSION}

Based on the results of the study that were obtained from interviews with informants and data analysis. It can be obtained, as follows: Renita Enceng Gondok Strategy in achieving success and maintaining business existence is by 1. Maintaining Quality. 2. Improving the Skilled of their Human Resource. 
Renita Enceng Gondok maintains quality by conducting training in making Enceng Gondok with different models. They use the materials which come from organic materials and not synthetic goods, such as plastic or rubber. So in terms of quality, the durability might be less than rubber or plastic but in terms of appearance it would be better because it is a handmade product.

Renita Enceng Gondok in the improvement of the skill of human resources by conducting training around Semarang, therefore the government asks Renita Enceng Gondok to be a leader for Enceng Gondok training in Semarang and Renita Enceng Gondok was willing to become an instructor, to teach theknowledge and techniques of making products from Enceng Gondok in 2019.

Renita Eceng Gondok explores creative ideas in the creation of a variety of Enceng Gondok handycrafts products advantages such as 1 . We Create a Very Different Weaving from Other type of Woven. 2. Every Month We Change the Product Design. 3. Coaching visit in Other Provinces.

\section{1) We Create a Very Different Woven from Other type of Woven.}

Renita Eceng Gondok try to make product designs that are different from the others. Because with this idea, Renita Eceng Gondok will be able to dominate the market share.

\section{2) Every Month We Have To Change the Product Design.}

In this case Renita Eceng Gondok always updates the types of products that they offered. He explained that most consumers always want to have a variety of models, so they do not feel bored

\section{3) Coaching Visits in Other Provinces}

Renita Eceng Gondok provides couching with other producers outside Central Java with due to improving, developing creativity and innovation, with the main goal is to get ideas that are useful for the comunity.

The Results of Creative Ideas Exploration that can be turned into the process of creating a variety of products advantages that were applied by Renita Eceng Gondok. Among them; 1. Various kinds of crafts, such as bags, sandals, miniatures, tissue boxes, frame, and others. 2. We made Renita Enceng Gondok as an informant at activities funded by APBN, namely on the management and manufacture of products originating from water Enceng Gondok. 
Forms of Government Support for the existence of Renita Eceng Gondok Business Activities the following condition is a form of Government support for the sustainability of Renita Eceng Gondok business activities. Government supports include; 1. We provide guidance to them, there are several methods of the guidance can be directly or indirectly. 2. Facilitating the exhibition, facilities for training both management and equipment. 3. Providing Sales Points at the MSME's Corner at Ambarawa Station.

The impact of Renita Eceng Gondok business activities in the environment around Banyubiru 1. Reducing unemployment 2. Income of the Community Around Rawa Pening. 3. Reducing Enceng Gondok Waste in Rawa Pening.

\section{1) Reducing Unemployment}

With Renita Enceng Gondok business in Banyu Biru Sub-district helping the surrounding community to obtain jobs by making Enceng Gondok handycraftss.

\section{2) The Community Income around Renita Enceng Gondok Business}

Increase the income of the community around Banyu Biru Rawa Pening both in plucking the Enceng Gondok, drying it, and production for the Enceng Gondok handycrafts.

\section{3) Reduce Waste Water HyacinthIn Rawa}

Enceng Gondok is one of harmful plant; with the existence of Renita Enceng Gondok it can reduce Enceng Gondok waste in Rawa Pening

Supporting and inhibiting factors of Renita Enceng Gondok in success and maintain the existence of the business.1. Affordable Prices. 2. The location is very strategic. 3. Perform Coaching. 4.Temporarely, they use Instragam and Facebook, as Marketing media, they don't use Application like Bukalapak, Shopee yet. 5. Increasing New Competitors.

\section{CONCLUSIONS}

Renita Eceng Gondok strategy to achieve success and maintain the existence of its business is to pay attention to materials, which come from organic materials. So in terms of quality the durability might be less than rubber or plastic but in terms of appearance it would be better because it is handmade. Second is the improvement of skilled human resources, so we plan to open trainings to make the employee ready to improve their skill and ready to compete with other products. How Renita Enceng Gondok explores 
creative to create various Enceng Gondok handycrafts products advantage. By looking from the internet we continue to make Woven patterns and develop them again according to the direction of Mr. Slamet in accordance with the different sandals models, there are several kinds of models for the straps, if it is for female talents then there are more models are available and also there are other variant of products. The results of the ideas exploration can be turn into the process of creating a variety of Renita Eceng Gondok product advantage. In the beginning, we only made shoes and sandals but by time we try to develop other products, such as tissue case, small jars, trash bins, frame and miniatures, glass for hotel construction, laundry baskets, and another product. The form of government support for the sustainability of the business activities of Renita Eceng Gondok includes that the government contributions to facilitate exhibitions, provide facilities for training about management, marketing, equipment, and other things. So the role of Local governments is very important guide them, there are several methods of couching session both direct or indirect, can use the government service budget. The impact of Renita Eceng Gondok business activities in the for the environtment around Banyu Biru sub-district. The people who live in that area work as workers which lead to help their financial condition, if there are lot of trainings available the neighborhood will join the training so they can improve their skill in turning Enceng Gondok to a useful craft which they can sell it after. Enceng Gondok is one of harmfull plant, and we can turn it into crafts which help them to improve their family income. The supporting and inhibiting factors of Renita Enceng Gondok in achieving success and maintaining the existence of its business include: Enceng Gondok as a material is easy to obtain and cheap. Easy to promote the product. The workers are always have free time and they have full support from their family. Inhibiting factors include: weather changes that affect the drying process of Enceng Gondok. Some workers are lacked of skill.

\section{IMPLICATIONS}

\section{Implications of these research are:}

1) To promote their product they also can use other social media, not only Instagram and Facebook, but also through Shopee, Bukalapak, and others.

2) The results of this study are expected to provide input to investors for stock investments by looking at the success of Renita Eceng Gondok in retaining 
customers.

3) Renita Eceng Gondok should continue to run social programs due to long-term benefits and to maintain the company's image in the community.

4) It is expected for Renita Enceng Gondok to cultivate Enceng Gondok they can maintain the existence of its business without damaging the environment because if Enceng Gondok are cautiously grow in Rawa Pening Lake it will damage the ecosystem of the Lake.

\section{REFERENCES}

Abidin, Zaenal. (2006). Filsafat Manusia: Memahami Manusia Melalui Filsafat. Bandung: Remaja Rosdakarya.

Afifah, Rifda Zahra. (2012). Analisis Bantuan Modal dan Kredit Bagi Kelompok Pelaku Usaha Mikro Oleh Dinas Koperasi UMKM Kota Semarang (Studi kasus KPUM di Kelurahan Pekunden Kecamatan Semarang Tengah). Semarang: Universitas Diponegoro. Diakses melalui http://eprints.undip.ac.id/35806/1/AFIFAH.pdf.

Algifri. (2003). Ekonomi Mikro : Teori dan Kasus. Yogyakarta: STIE YKPN.

Andari, Ressa. (2011). Pengaruh Kompetensi Pengusaha, Skala Usaha, dan Saluran Pemasaran Terhadap Keberhasilan Usaha (Survey Pada Industri Bawang Goreng di Kabupaten Kuningan). Bandung: UPI.

Anwae, Dessy. ((2003). Kamus Lengkap Bahasa Indonesia. Surabaya: Amelia.

Anwas, Oos M. (2014). Pemberdayaan Masyarakat di Era Global. Bandung: Alfabeta.

Arikunto, Suharsimi. (2002). Prosedur Penelitian Suatu Pendekatan Praktek. Jakarta: Rineka Cipta. . (2006). Metode Penelitian Kualitatif. Jakarta: Bumi Aksara.

Asri, Marwan. (1986). Manajemen Perusahaan Pendekatan Operasional.Yogyakarta: BPFE.

Assauri, Sofjan. (2011). Manajemen Pemasaran. Jakarta: Rajawali Pers.

Badan Pengendalian Dampak Lingkungan Sumatera Utara. (2003). Eceng Gondok di Danau Toba. Medan: BPDL Sumut.

D’Aveni, Richard., and Gunther, Robert. (1994). Hypercompetition: Managing the Dynamics of Strategic Maneuvering. New York: Free Press.

Danoko, Florance. (2008). Strategi Pengembangan Usaha Kecil. Jakarta: Universitas Kristen Krida Wacana.

Diti, Raisa. (2014). Hubungan Antara Karakteristik Wirausahawan dengan Keberhasilan Usaha Industri Kecil Kemplang (Studi Kasus di Industri Kecil Kemplang Kampung Sekip Rahayu Kota Bandar Lampung). Lampung: Universitas Lampung. Skripsi tidak diterbitkan.

Djamari. (1975). Beberapa Aspek Geografi Industri. Bandung: IKIP Bandung. 
Fadli, Ahmad. (2017). UMKM Indonesia masih Peringkat Ketiga di ASEAN. Diakses melalui http://industry.co.id/read/2313/umkm-indonesia-masih-peringkat-ketiga-diaseanGerbono, Anton, dan Djarijah, Abbas Siregar. (2005). Kerajinan Eceng Gondok. Yogyakarta: Kanisius.

Griffin, Ricky W., dan Ebert, Ronald J. (2007). Bisnis Edisi Kedelapan. Jakarta: Erlangga.

Hafsah, Muhammad Jaffar. (2004). Upaya Pengembangan Usaha Kecil dan Menengah. Infokop, Nomor 25 Tahun xxx: 40-44.

Heyne, K. (1987). Tumbuhan Berguna Indonesia Jilid II. Bogor: Badan Penelitian dan Pengembangan Kehutanan Departemen Kehutanan.

Indriyatni, Lies. (2013). Analisis Faktor-Faktor Yang Berpengaruh Terhadap Keberhasilan Usaha Mikro dan Kecil. Jurnal STIE Semarang, Volume 5 Nomor 1, Edisi Februari 2013. ISSN: 2252-7826, hlm. 54-70.

Kartasasmita, Ginandjar. (1996). Strategi Pengembangan Usaha Kecil: Kesempatan dan

Tantangan dalam Proses Transformasi Global dan Nasional. Seminar Nasional HUT HIPPI Jakarta.

Kasmir. (2006). Kewirusahaan. Jakarta: Raja Grafindo Persada.

Kasmir. (2008). Manajemen Perbankan. Jakarta: Raja Grafindo Persada.

Kotler, Philip, dan Keller, Kevin Lane. (2008). Manajemen Pemasaran Edisi Ketiga Belas

(Terjemahan oleh Bob Sabran). Jakarta: Erlangga.

Kotler, Philip. (2002). Manajemen Pemasaran. Jakarta: Prehallindo.

Kotler, Philip. (2005). Manajemen Pemasaran, Edisi Kesebelas. Terjemahan oleh Benyamin Molon. Jakarta: Intan Sejati Klaten.

Koes. (2010). Telaga Rawa Penin, Masyarakat Banyubiru, dan Eceng Gondok. Diakses melalui http://catatan.go.blogspot.com/20100801archieve.html.

Lail, Nuzulul. (2008). Penggunaan Tanaman Eceng Gondok (Eichornia Crassipes)

Sebagai Pre Treatment Pengolahan Air Minum Pada Air Selokan Mataram.

Yogyakarta: Universitas Islam Indonesia. Tugas Akhir tidak diterbitkan.

Mahoney and Pandian. (1992). The Resouce-Based View Within The Conversation of

Strategic Management. Strategic Management Journal Volume 13 Number 5 (June 1992(: 363-380: John Wiley \& Sons.

Moleong, Lexy. (2000). Metodologi Penelitian Kualitatif. Bandung: Remaja Rosdakarya. . (2007). Metode Penelitian Kualitatif. Bandung: Remaja Rosdakarya.

Mubyarto. (1989). Oengantar Ekonmi Pertanian. Jakarta: LP3S.

Onyango, J. P., and Ondeng, M. A. (2015). The Contribution of The Economic Development of Ripatian Communities in Dunga and Kichinjio of Kisumu Central Subcountry, Kenya. American Journal of Renewable and Sustainable Energy, Volume 1 Number 3, pp 128-132.

Pandey, B. P. (1980). Plant Anatomi. New Dehli: S. Chard and co. Ltd.

Priyatno, Sony Heru. (2009). Mengembangkan Pendidikan Kewirausahaan di Masyarakat Androgogia. Jurnal PNFI Volume 1 Nomor 1, pp. 57-82. 
Purnama, Chamdam. (2010). Motivasi dan Kemampuan Usaha dalam Meningkatkan Keberhasilan Usaha Industri Kecil (Studi Pada Industri Kecil Sepatu di Jawa Timur). Jurnal Manajemen dan Kewirausahaan, Volume 12 Nomor 2, September 2010, hlm. 17-184.

Purnavita, Sari., Sutanti, Sri., Haryanto, Poedji. (2016). Produksi Sandal dan Tas Eceng Gondok di Kelompok Usaha Renita dan Sekar Melati. E-DIMAS, EducationPengabdian Kepada Masyarakat, Jurnal Pengabdian Kepada Masyarakat Volume 07 Nomor 1, Maret 2016.

Putong, Iskandar. (2003). Pengantar Ekonomi Mikro dan Makro. Edisi Kedua. Jakarta: Ghalia Indonesia.

Rangkuti, Fredy. (2002). The Power of Brands: teknik Mengelola Brand Equity dan Strategi Pengembangan Merek. Bandung: Remaja Rosdakarya.

Riyanti, Benedicta Prihatin Dwi. (2003). Kewirausahaan dari Sudut Pandang Psikologi Kepribadian. Jakarta: Grasindo.

Ratnasari, Alfina Dwi. (2017). Analisis Faktor-Faktor Yang Mempengaruhi Keberhasilan Usaha Bisnis Online Shop di Samarinda. Volume 5, Nomor 1. ISSN: 2355-5408. Diakses melalui http://ejournal.adbisnis.fisip-unmul.ac.id/site/wpcontent/uploads/2017/02/JURNAL\%20pdf\%20(02-27-17-07-35-06).pdf

Rudi. (2003). Tumbuhan Eceng Gondok. Jakarta: Agromedia Pustaka.

Saputra, Adi. (2013). Faktor-Faktor Yang Mempengaruhi Keberhasilan Usaha Pengepul Sampah di Kota Yogyakarta. Universitas Ahmad Dahlan. Diakses melalui http://jurnal.fe.uad.ac.id/wp-coontent/upload/adi-saputra-surahma-astimulasari.pdf.

Setiawan, Ebia. (2011). Kamus Lengkap Bahasa Indonesia. Jakarta: Pusat Bahasa.

Setyobudi, Andang. (2007). Peran Serta Bank Indonesia dalam Pengembangan Usaha Mikro Kecil dan Menengah. Jurnal Hukum Perbankan dan Kebanksentralan 5, 19-35.

Sianturi, Christin Octarina dan Tyas, Wido Prananing. (2018). Kajian Kontribusi UMKM Berbasis Rumah Eceng Gondok Melalui Penggunaan Internet Terhadap Pendapatan Pelaku Usaha di Kawasan Rawa Pening. Jurnal Pengembangan Kota Volume 6 Nomor 2 (118-126) DOI: 1.14710/jpk.6.2.118-126. ISSN: 2337-7062, e-ISSN: 2503-0361.

Sjafirah, N. A., dan Prasanti, D. (2016). Penggunaan Media Komunikasi Budaya Lokal Bagi Komunitas Tanah Aksara. Studi Deskriptif Kualitatif tentang Penggunaan Media Komunikasi dalam Eksistensi Budaya Lokal Bagi Komunitas Tanah Aksara. JIPSI, Volume VI Nomor 2: 39-30.

Soekanto, Soerjono. (1994). Sosiologi Suatu Pengantar. Jakarta: Raja Grafindo Persada.

Sosrodihardjo, Soedjito. (1986). Transformasi Sosial Menuju Masyarakat Industri. Yogyakarta: Tiara Wacana Yogya.

Steenis, Van. (1978). Flora. Jakarta: Pradnya Paramita.

Steinhoff, Dun., and Burgess, John F. (1993). Small Business Management Fundamentals. 6th ed. New York: Mcgraw Hill, Inc. 
Sudarto. (1997). Metodologi Penelitian Filsafat. Jakarta: Raja Grafindo Persada.

Sugiyono. (2007). Metode Penelitian Kuantitatif Kualitatif dan R\&D. Bandung: Alfabeta. Sukman, Y., dan Yakup. (2002). Gulma dan Teknik Pengendaliannya. Jakarta: Raja Grafindo Persada.

Sulistyowati, Eny., dan Lestari, Nining Sofiati. (2016). Faktor-Faktor Penentu Keberhasilan Usaha Kecil dan Menengah (UKM) di Kota Yogyakarta. Jurnal Maksipreneur: Manajemen, Korperasi dan Enterpreneurship, Volume V Nomor 1, Desember 2016. P-ISSN 2089-550X e-ISSN 2527-6638.

Sumarwan, Ujang. (2003). Perilaku Konsumen: Teori dan Penerapannya dalam Pemasaran. Jakarta: Ghalia Indonesia.

Suprihatin. (2007). Terampil Menganyam Eceng Gondok. Yogyakarta: Pusat Ilmu Berguna.

Suryana. (2009). Kewirausahaan, Konsep dan Realita Pada Usaha Kecil, Panduan Mahasiswa, Pengusaha, Umum. Bandung: Alfabeta.

Suryana. (2010). Metode Penelitian Model Praktis, Penelitian Kuantitatif dan Kualitatif. Bandung: LIPI.

Sutawi. (2002). Manajemen Agrbisnis. Malang: UMM.

Sutrisno, Joko., dan Lestari, Sri. (2006). Kajian Usaha Mikro Indonesia. Jurnal Pengkajian Koperasi dan UKM Nomor 2 Tahun I-2006.

Tambunan, Tulus. (2012). Usaha Mikro Kecil dan Menengah di Indonesia, Isu-Isu Penting. Jakarta: LP3ES.

Tanjung, D. B. (2012). Analisis Faktor-Faktor Keberhasilan Toko Emas Sriwijaya Gunung Sitoli. Medan: Jurnal Ilmu Sosial USU.

TAP MPR Nomor XVI/MPR-RI/1998 tentang Politik Ekonomi Dalam Rangka Demokrasi Ekonomi.

Undang-Undang Nomor 20 Tahun 2008 tentang Usaha Mikro Kecil dan Menengah.

Usman, Husaini dan Akbar, Purnomo Setiadi. (2009). Metodologi Penelitian Sosial. Jakarta: Bumi Aksara.

Utami, Christina Widhya. (2006). Manajemen Ritel Strategi dan Implementasi Ritel Modern. Jakarta: Salemba Empat.

Wahyudin, Dian. (2013). Peluang atau Tantangan Indonesia Menuju ASEAN ECONOMICS COMMUNITY 2015. Semarang: Lembaga Penerbitan Universitas Diponegoro.

Warsito. (2016). Sosiologi Industri. Surabaya: Jaudar Press.

Widayana, Lendy. (2006). Knowledge Management, Meningkatkan Daya Saing Bisnis. Malang: Bayu Media.

Widianto, L. S. (1997). The Effect of Heavy Metal on The Growth of Water Hyacinth. Bogor: Proceed Symposium on Past Seameo-Biotrop.

Yanney, J. Ewusie. (1990). Ekologi Tropika. Bandung: ITB.

Zimmerer, W. Thomas., and Scarborough, Norman M. (2000). Pengantar Kewirausahaan dan Manajemen Bisnis Kecil (Edisi Bahasa Indonesia). Jakarta: Salemba Empat. 